\author{
D.A. Abirov ${ }^{*}$ \\ Zhetysu university named after I.Zhansugurov, Taldykorgan, Kazakhstan \\ (E-mail:abirdan@mail.ru)
}

\title{
Content system of the lyceum and gymnasium educational program
}

\begin{abstract}
This article provides an overview of the study of the problems of developing the continuity of the content of training programs in lyceums and gymnasiums. Continuity of education is considered as a phenomenon that defines as a potential qualitative growth of creative abilities of students ' personality. The article examines the content of continuity of education, as well as in domestic works, describes the main factors of formation of the structural and procedural component. The article describes long-term plans that allow us to predict and implement innovations in certain contexts of the educational sphere of lyceums and gymnasiums. There are several main directions in the field of education. Among them, the practical idea of development based on information and communication technologies, the rejection of outdated collective forms of education. Including the need to develop motivation for self-education and self-development in students and is focused on the development of creative education. As well as in the system of education in lyceums and gymnasiums, it is connected with the concept of continuing education. As a clear example, the author proposed a comprehensive and multi-factor plan for the development of continuous transformations of the curriculum system and the content of training in lyceums and gymnasiums. The article also offers a scheme of training stages, the main goal of which is the expected result.
\end{abstract}

Keywords: continuity of education, transformation of the content of the educational process, innovations of the training system, modernization, specialized training, innovative educational technologies, individualization of training.

\section{Introduction}

Today there are several main directions in the field of education. The first direction is clearly applied to the practical idea of development based on information and communication technologies. The second direction involves the rejection of outdated collective forms of education. At the same time, the learning paths are individualized and built depending on the abilities and capabilities of each student. The third direction is based on the need to develop motivation for self-education and self-development among students. This will instill the meaning of the activity that the student performs. The fourth direction is focused on the development of creative education. The fifth direction of transformation of the educational system in lyceums and gymnasiums is associated with the concept of lifelong education [1].

As V.P. Zinchenko notes, lifelong education is considered as a single system that includes secondary general education and a higher professional institution. In addition, this complex includes advanced training courses, retraining of personnel, as well as self-education. At the same time, the principle of lifelong education is continuity [2].

We conducted a theoretical analysis on the topic of our research. Based on this, the following scientists were identified who made a contribution to the development of the educational system in relation to certain aspects. The development of educational institutions as a complex and multi-factor system was considered in their works by E. Marx and M. Petri[3], as well as many others. A.V. Khutorsky[4], A.S. Kuryshev [5], A.M. Novikov[6], A. Kuznetsov[7] and others were engaged in the study of the problem of professionalism, as well as its improvement. Ideas for the development of institutions of primary vocational education in the context of multilevel education were disclosed in the works of V.A. Bolotov [8], G.M. Romantsev [9], A.A. Barbarig [10] and others. Models of development of professional competence were considered in the works of O.Ya..Dymarskaya [11], R.V. Bessonov [12], A.N. Dzhurinsky [13], V.K. Bityukov [14], Yu.V. Shmarion [15] and others. Also, the study of the problem of increasing the professional competence of teachers of lyceums and gymnasiums was considered in the works of O.P. Okolelov [16], V.V. Serikov [17], E.A. Yamburg [18], V.I. Zagvyazinsky [19].

\footnotetext{
${ }^{*}$ Corresponding author's e-mail: abirdan@mail.ru
} 


\section{Experimental}

It should be noted that, to a large extent, the expansion of the concept of education is identified with formal learning and interprets any activity as educational assets. In the education system of lyceums and gymnasiums, taking into account innovative processes, the most important educational functions are performed by social institutions. That is, this list includes not only educational institutions, but also microfactors (family, circle of friends, etc.) [20, p. 235].

At the heart of the continuity of the educational system of lyceums and gymnasiums, the formation of market mechanisms, the formation of educational services is a priority. At the same time, globality is a hallmark of the continuity of educational structures. The new system emerges on the basis of individualized and creative education. The extensive and intensive rhythm of development of the education system allows us to assert that information systems can provide a positive dynamics in the development of lifelong education in lyceums and gymnasiums [21].

The system-forming factors of the process of formation of the system of continuing education are:

- elimination of monopolism in the channel of educational services, on the broadcast of social experience. At the same time determining competitiveness;

- integration of the learning process in lyceums and gymnasiums, determines the implementation of the environmental standard [22];

It should be noted that in terms of theoretical justification, the development of lifelong education in lyceums and gymnasiums is based on the principle of complementarity of technological and search methods of teaching. Accordingly, a complex of organizational and pedagogical aspects acts as a condition for the implementation of the transformation process of curricula and training programs in lyceums, as well as gymnasiums. Also, the professionally oriented nature of the educational process involves the management of creative activities. At the same time, we should note that despite the outward simplicity of the formulations of the named principles, the latter describe a far from trivial approach to the problem of managing an educational institution [23].

The evolution of the education system is the result of the natural formation of the social stratum, which is focused on the elite quality, as B.S. Gershunsky asserts in his research, the lyceum is an institution that has a profile focus and is focused on a higher educational institution. Considering that the lyceum is characterized by a basic component, which implies increased attention to special courses and subjects. In addition, there is a need for a more thorough, high-quality profiling training of specialization [24].

M.B. Pildee in his works describes the transition to innovative trajectories as an opportunity that provides a wide variety of forms of educational processes. Also, in accordance with the strategic goals of educational processes, development points are determined:

- the development of the educational process in the lyceum provides a system of continuous education, since it passes through all stages, starting from pre-school and ending with professional;

- the transition to individual educational programs, as well as to individual curricula, becomes a resource for further improvement of education in the lyceum and gymnasium;

- the quality of education is based on the informatization of the educational process;

- there is also an improvement in the forms of management in the framework of the implementation of the model of civil education;

- the needs of the population in the quality of educational services lead to the diversification of educational systems [25].

As a clear example, we offer a comprehensive and multi-factor plan for the development of continuity of the system of curricula and educational content in lyceums and gymnasiums.

Table 1

\section{Development plan of the educational system in lyceums and gymnasiums}

\begin{tabular}{|l|l|}
\hline \multicolumn{1}{|c|}{ Stages } & \multicolumn{1}{c|}{ Main goal } \\
\hline \hline \multicolumn{1}{|c|}{1} & \multicolumn{1}{c|}{2} \\
\hline Improving the academic level of education & $\begin{array}{l}\text { Creation of a system of continuous education, providing individual- } \\
\text { ization of the educational process and effective self-determination. }\end{array}$ \\
\hline $\begin{array}{l}\text { Development and strengthening of the person- } \\
\text { nel potential of lyceums and gymnasiums. }\end{array}$ & $\begin{array}{l}\text { Creation of a professional team that effectively solves the problems } \\
\text { of the development of the educational system. }\end{array}$ \\
\hline Development of the process of informatization & integration of information and communication technologies into the \\
\hline
\end{tabular}


Content system of the lyceum and gymnasium educational program..

\begin{tabular}{|c|c|}
\hline 1 & 2 \\
\hline of education in lyceums and gymnasiums & educational process. \\
\hline $\begin{array}{l}\text { Development of public and state forms of } \\
\text { government and social partnership. }\end{array}$ & $\begin{array}{l}\text { building and implementing an effective model of state and public } \\
\text { management of the educational process. }\end{array}$ \\
\hline $\begin{array}{l}\text { Development of the system of additional edu- } \\
\text { cation }\end{array}$ & $\begin{array}{l}\text { building a wide and multi-level network of additional education } \\
\text { (additional educational services) that create optimal favorable con- } \\
\text { ditions for free and maximum satisfaction of various educational } \\
\text { needs. }\end{array}$ \\
\hline $\begin{array}{l}\text { Implementation of preventive measures to } \\
\text { prevent social orphanhood }\end{array}$ & $\begin{array}{l}\text { creation of conditions for the availability of high-quality education } \\
\text { and the full development of the child in accordance with his per- } \\
\text { sonal characteristics, state of somatic health and social status. }\end{array}$ \\
\hline
\end{tabular}

\section{Results and Discussion}

Thus, the implementation of the above stages, as well as the systemic development of the content of education, the management process, and the transformation of the staff in lyceums and gymnasiums, can provide a transition to a new stage of the organizational and content model of education. Within the framework of the proposed program for the development of lifelong learning, it is also advisable to highlight the implementation results and indicators that determine success.

Table 2

Indicators of the effectiveness of the implementation of the long-term plan for the development of the education system in lyceums and gymnasiums

\begin{tabular}{|c|c|}
\hline Results & Development indicators \\
\hline 1 & 2 \\
\hline \multicolumn{2}{|l|}{$\begin{array}{l}\text { 1.Creation of a model of lifelong education that provides compe- } \\
\text { tent personal and professional self-determination of graduates of } \\
\text { lyceums and gymnasiums }\end{array}$} \\
\hline $\begin{array}{l}\text { - Regulatory documents ensuring the functioning of the model. } \\
\text { - Organizational model of education continuity. } \\
\text { - New organizational model of the educational process. } \\
\text { - Regulatory documents for the organization of specialized train- } \\
\text { ing based on an individual curriculum. } \\
\text { - The model of integration with institutions of higher profession- } \\
\text { al education in the context of increasing individualization. }\end{array}$ & $\begin{array}{l}\text { Availability and effective functioning of the } \\
\text { lifelong education model. } \\
\text { The transition from the classroom system to } \\
\text { new forms of organization of the educational } \\
\text { process: } \\
\text { - distance learning, } \\
\text { - educational streams, } \\
\text {-individual sessions. }\end{array}$ \\
\hline \multicolumn{2}{|l|}{$\begin{array}{l}\text { 2. Development of an educational program for senior preschool } \\
\text { children in order to increase the level of readiness for learning at } \\
\text { the initial stage of lyceums and gymnasiums }\end{array}$} \\
\hline $\begin{array}{l}\text { An educational program that provides children with equal starting } \\
\text { opportunities, taking into account the requirements of education. } \\
\text { - Educational programs for senior preschool children. } \\
\text { - Methodical recommendations for preparing for teaching in pri- } \\
\text { mary school. }\end{array}$ & $\begin{array}{l}\text { Implementation of an educational program for } \\
\text { senior preschool children. } \\
\text { An increase in the number of children with a } \\
\text { high level of readiness to master the educational } \\
\text { program. }\end{array}$ \\
\hline \multicolumn{2}{|l|}{$\begin{array}{l}\text { 3. Creation of a continuous system of specialized training and } \\
\text { specialized training, taking into account the expansion of oppor- } \\
\text { tunities for the implementation of individual educational requests. }\end{array}$} \\
\hline $\begin{array}{l}\text { - A new version of the curriculum, ensuring the implementation } \\
\text { of individual educational trajectories. } \\
\text { - Modified and original curricula of elective subjects and } \\
\text { courses. } \\
\text { - The system of continuity in the content of education between } \\
\text { all levels. } \\
\text { - Individual educational programs for gifted children. } \\
\text { - Interaction of the lyceum with other educational institutions } \\
\text { within the educational network. }\end{array}$ & $\begin{array}{l}\text { Improving the quality of education within the } \\
\text { Lyceum model of continuing education. } \\
\text { Increase in the number of programs mastered by } \\
\text { teachers that implement the relevant state stand- } \\
\text { ard. } \\
\text { The increase in the number of programs of elec- } \\
\text { tive courses. } \\
\text { Increase in the number of students in grades } 8- \\
11 \text { who study according to individual curricula } \\
\text { and individual educational programs. } \\
\text { Realization of the creative potential of gifted } \\
\text { children, increasing the effectiveness of their }\end{array}$ \\
\hline
\end{tabular}




\begin{tabular}{|c|c|}
\hline 1 & 2 \\
\hline & $\begin{array}{l}\text { participation in intellectual competitions of var- } \\
\text { ious levels. }\end{array}$ \\
\hline $\begin{array}{l}\text { 4. Increasing the level of implementation of new educational } \\
\text { technologies that ensure the development of students ' compe- } \\
\text { tence in the field of independent cognitive activity. }\end{array}$ & \\
\hline $\begin{array}{l}\text { Development and implementation of modern effective education- } \\
\text { al technologies by all teachers. } \\
\text { - Expanding opportunities for individualization of the education- } \\
\text { al process. } \\
\text { - Modern systems for evaluating students ' academic achieve- } \\
\text { ments: } \\
\text { - formative education in primary schools; } \\
\text { - summative (rating) assessment in grades } 5-11 \text {. }\end{array}$ & $\begin{array}{l}\text { Improving the quality of training. } \\
\text { Increase in the number of students enrolled in } \\
\text { training using modern educational technologies: } \\
\text { ICT, project-based, module-rating, } \\
\text { etc.Increasing the degree of individualization of } \\
\text { training. Improving the level of students ' com- } \\
\text { petence in the field of independent cognitive } \\
\text { activity. }\end{array}$ \\
\hline
\end{tabular}

Based on the potential effectiveness of the presented program for the development of lifelong learning, we can highlight the purpose of the program. Thus, the goal is to create conditions for the development of key competencies in students. As a result, this will provide them with successful socialization and active adaptation in the labor market. At the same time, the development plan complies with the educational standard programs.

According to V.I. Baidenko, a specialized educational and methodological package can provide the individuality of the cognitive trajectories of the development of educational activity [26]. At the same time, in the studies of T.Yu. Lomakin [27], profile training programs are subdivided into logical, figurative, mixed by the nature of educational and cognitive activity.

Thus, based on the profiling aspect of the development of continuous education, several functional tasks are distinguished:

1. Improvement of the educational process;

2. Innovative approaches to the formation of a new educational content, improvement of curricula;

3. Development of new academic subjects, special courses that will contribute to the intellectual development of the personality of students;

4. Development of individual curricula, taking into account individual cognitive abilities;

5. Application of advanced educational and methodological kits, updating the literary fund;

6. Creation of educational, laboratory and technical bases for high-quality implementation of educational programs;

7. Development of the system of school self-government, with the aim of developing civic position;

8. Formation of healthy lifestyle skills;

According to E.N. Ovcharenko [28], in the system of transformation and renewal of educational services, there are several components of improving teaching technologies:

- the use of problem learning;

- possession of the methodology for creating individual curricula;

- development of extracurricular, project and scientific activities;

- development of forms of organizing students' independent work;

- development of motivation for the use of relevant technologies.

\section{Conclusion}

Considering the integration processes in the education system, the introduction of the practice of majoring education at the senior level of general education can ensure the implementation of continuity mechanisms. At the same time, a variant of the continuity of the lyceum-university is proposed. According to V.G. Ryndak [29] and T.V. Chelysheva [30], continuity should be considered as a methodological principle that plays a connecting role in the theory of knowledge, as a general pedagogical principle that provides an inextricable connection between individual components, stages and stages of education, as a didactic principle that determines changes in the content of education, methods of teaching scientific disciplines, methods and means of forming the skills of independent educational activity, as well as the implementation of the principles of scientific character, accessibility and sequence of training. 
Also, according to L.N. Alekseeva [31], an interactive approach to the continuity of learning, should be considered as a guideline for the use of interactive learning modes through innovative computer technologies, the composition of which corresponds to the pedagogical tasks of the personality-oriented focus of the epistemological cycle and the levels of the knowledge systematic model.

Methodical work in lyceums and gymnasiums involves:

- increasing the efficiency of the methodological council of the educational institution;

- Creation of a moderator system for advanced training of teachers: organize training for teachers in the use of new educational technologies, as well as the organization of research activities of students;

- increasing the efficiency of the disciplinary cycles;

- reorientation of the organization of methodological work from vertical to horizontal, creation of creative groups of teachers working on the problem of health retention, project activities, work with gifted children, school government, etc.;

- organization and improvement of the methodological center for young and novice teachers [32].

Modernization of the way of life of lyceums and gymnasiums: streamlining the regulatory framework; improvement of the self-government system; strengthening and developing the traditions of the Lyceum; introduction of an automated control system for the lyceum; inclusion of the governing council in the assessment of the effectiveness of the development of the lyceum.

Improving the educational environment: improving work with parents; development of relations with government agencies; development of regulatory, organizational, pedagogical, financial mechanisms of network interaction of educational institutions [33].

Despite the fact that the study of the continuity of the development of educational content, curricula and programs remains one of the urgent problems of our time, we believe that an important component of the development of innovative approaches to the general development of students, as well as the basis of activity.

Each of the above-described structural components of the development of the system for the continuity of the content of the basic standards of education should work in an integrated manner and in a coordinated manner. Relying on the fundamental works of great teachers, it should be noted that the educational institution equips the child with the necessary skills and knowledge in accordance with age characteristics. However, it must be remembered that advanced technologies and teaching aids can provide the development of cognitive motivation in students. In the future, this will stimulate successful interaction with the outside world, in the cultural, social, economic and environmental aspects. The ability to keep up with progress and taking into account the psychophysiological characteristics of students is a high-quality resource for the development of personal content, and on a global scale it allows to form a highly educated and competitive society.

Thus, in this article we have made an attempt to consider the key directions for studying the continuity of the development of the content of educational standards and curricula in lyceums and gymnasiums. We have identified long-term plans and an algorithm for potentially effective activities. Consequently, it is assumed here that the scientific and practical specificity of this topic is relevant and requires a concentrated approach to implementation.

\section{References}

Погашник И.М. Управление развитием школы / И.М. Погашник. - М., 1995.

Зинченко Г.П. Аффект и интеллект в образовании / В.П. Зинченко. — М., 1995.

Маркс Э. Развитие школы: Модели и изменения / Э. Маркс, М. Петри. - Калуга: Калужская типография стандартов, 1993.

4 Хуторской А.В. Ключевые компетенции как компонент личностно-ориентированной парадигмы образования / А.В. Хуторской // Народное образование. - 2003. - 584 с.

5 Курышев А.С. Проектирование систем непрерывного открытого профессионального образования: теория и практика / А.С. Курышев. - Калининград: БФАРФ, 2007. - С. 138.

6 Новиков А.М. Методика обучения / А.М. Новиков. - 2-е изд. - М.: Эгвес, 2006. — С. 488.

7 Концепция профильного образования на старшей ступени общеобразовательной школы: проект / рук. проекта А. Кузнецов, А. Пинский. - М., 2002. - С. 36.

8 Болотов В.А. Компетентностная модель: от идеи к образовательной программе / В.А. Болотов. - 2003. - № $10 .-$ C. $8-14$.

9 Барбарига А.А. Среднее и средне-специальное образование в современной Англии / А.А. Барбарига. — Киев, 2005. 
10 Бессонов Р.В. Специфика преподавания в специализированной школе / Р.В. Бессонов. - М.: Педагогика, 2006. № 7. - С. 23-29.

11 Джуринский А.Н. Развитие образования в современном мире / А.Н. Джуринский. - М., 2002.

12 Шмарион Ю.В. Проектирование образовательных систем (системно-контекстуальный подход) / Ю.В. Шмарион. Белгород: БелГУ, 2003.

13 Загвязинский В.И. Инновационные процессы в образовании и педагогической науке / В.И. Загвязинский // Инновационные процессы в образовании: сб. науч. тр. - Тюмень, 1990.

14 Дегтярев Е.А. Вопросы управления современной школой / Е.А. Дегтярев. — Ростов-на-Дону, 2005.

15 Алымова Н. Школьное самоуправление: структура, рекомендации, нормативы / Н. Алымова, Е. Надточий. - М.: Учитель, 2014. - 139 с.

16 Сергеева В.П. Профилактика образования в общеобразовательном учреждении / В.П. Сергеева. — М., 2011. 1990.

17 Гершунский Б.С. Перспективы развития системы непрерывного образования / Б.С. Гершунский. - М.: Педагогика,

18 Пилдее М.Б. Система образовательных учреждений в контексте модернизации образования / М.Б. Пилдее. — Волгоград, 2011.

19 Биденко В.И. Стандарты непрерывного образования: современное состояние / В.И. Биденко. - М.: Научноисследовательский центр проблем качества подготовки, 1998.

20 Ломакина Т.Ю. Современный принцип развития непрерывного образования / Т.Ю. Ломакина. — М.: Наука, 2006.

21 Сериков В.В. Образование и личность: теория и практика проектирования педагогических систем / В.В. Сериков. М.: Логос, 1999. - С. 271.

22 Рындак В.Г. Непрерывное образование и развитие творческого потенциала учителя (теория взаимодействия) / В.Г. Рындак. - М.: Педагогический вестник, 1997.

23 Челышева Т.В. Непрерывное образование как целостная образовательная система: теоретические аспекты / Т.В. Челышева. - М.: Апкипро, 2001.

24 Алексеева Л.Н. Инновационные технологии как ресурс эксперимента / Л.Н. Алексеева // Учитель. — 2004. — № 3. - C. 28 .

25 Молчанова Т.К. Составление образовательных программ / Т.К. Молчанова, Н.К. Виноградова. - М.: Перспектива, 2001.

26 Даутова О.Б. Современные педагогические технологии в профильном обучении: учеб.-метод. пос. для учителей / О.Б. Даутова, О.Н. Крылова; под ред. А.П. Тряпицина. - СПб.: КАРО, 2006.

27 Околелов О.П. Персонализированное обучение: моногр./О.П. Околелов.— М.: Директ-Медиа, 2013. — С. 122.

28 Овчаренко Е.Н. Интеграционные процессы как фактор развития образовательного пространства в поликультурном регионе: моногр. / Е.Н. Овчаренко, А.А. Шогенов. - М.: ФИРО, 2008. - С. 305.

29 Романцев Г.М. Профессиональные педагогические понятия: словарь / Г.М. Романцев, В.А. Федоров, И.В. Осипова, О.В. Тарасюк. - Екатеринбург: Изд-во Рос. гос. проф.-пед ун-та, 2005. — С. 456.

30 Дымарская О.Я. Социально-гуманитарное образование: ориентации, практики, ресурсы совершенствования / О.Я. Дымарская, Д.Л. Константиновский, Е.Д. Вознесенская, Г.А. Чередниченко. — М.: ЦСП, 2006.

31 Битюков В.К. Проектирование и реализация многоуровневой модели профессионального образования / В.К. Битюков, Е.Д. Чертов, А.Т. Кондауров; науч. ред. З.Д. Жуковская — Воронеж: Б.И., 2003.

32 Асмолов А.Г. Формирование универсальных учебных действий в основной школе: от действия мысли / А.Г. Асмолов, Г.В. Бурменская, И.А. Володарская. - М., 2011.

33 Ямбург Е.А. Гармония педагогических парадигм - стратегия развития образования: сб. науч. ст. по материалам Междунар. науч.-практ. конф. «Проблемы внедрения психолого-педагогических исследований в систему образования» / Е.А. Ямбург. - М., 2004.

\section{Д.А. Абиров}

\section{Лицей мен гимназияның оку бағдарламаларының мазмұндық жүйесі}

Мақалада лицейлер мен гимназияларда оқыту бағдарламаларының үздіксіз мазмұнын дамыту мәселесі зерттелген. Білім берудің үздіксіздігі окушылардың жасампаздық мүмкіндіктерінің әлеуетті сапалы өсуі ретінде айқындайтын құбылыс ретінде қарастырылды. Мақалада үздіксіз білім берудің мазмұны, сондай-ақ отандық еңбектерде зерттелген, құрылымдық және іс жүргізу құрамдастарын қалыптастырудың негізгі факторлары сипатталды. Лицейлер мен гимназиялардың білім беру саласының белгілі бір контекстіне инновацияларды енгізуді болжауға, жүргізуге мүмкіндік беретін перспективалық жоспарлар сипатталған. Білім беру саласында ақпараттық және коммуникациялық технологиялардың дамуын ескере отырып, ескірген ұжымдық оқыту формаларынан бастарту керек. Заман талабына сай қойылатын басты талап оқушылардың оқу материалдарының практикалық жағынан тиімді ұсынылуына мүмкіндік беру. Сонымен қатар оқушылардың бойына өзін-өзі тәрбиелеу мен өзін-өзі бәсекеге қабілетті, ақпараттық-коммуникациялық технологияларды жетік меңгерген ақпараттық мәдениетін қалыптастыру. Сондай-ақ лицейлер мен гимназиялардағы оқыту жүйесі үздіксіз білім беру тұжырымдамасымен байланысты. Көрнекі мысал ретінде автор оқу жоспарлары жүйесінің үздіксіздігін және лицейлер мен гимназияларда оқыту мазмұнын дамытудың кешенді және 
көп факторлы жоспарын ұсынған. Мақалада сонымен қатар оқыту кезеңдерінің негізгі мақсат схемасы күтілетін нәтижелері ұсынылған.

Кілт сөздер: үздіксіз білім беру, оку процесінің мазмұнының өзгеруі, оқыту жүйесінің инновациясы, жаңғырту, бейіндік оқыту, инновациялық оку технологиялары, оқытуды дараландыру.

\section{Д.А. Абиров}

\section{Система содержания учебной программы лицея и гимназии}

В статье изучено содержание непрерывности образования и основные факторы формирования структурной и процессуальной составляющих. Описаны перспективные планы, которые позволяют прогнозировать, проводить внедрение инноваций в определенные контексты образовательной сферы лицеев и гимназий. Выделены несколько основных направлений в сфере образования. Среди них практическая идея развития на базе информационных и коммуникационных технологий, отказ от устаревших коллективных форм обучения. В том числе обоснованы необходимость развития мотивации у учащихся к самообразованию, саморазвитию и ориентирование на развитие созидающего образования. Все это связано с концепцией непрерывного образования в лицеях и гимназиях. В качестве наглядного примера автором предложен комплексный и многофакторный план развития непрерывности трансформаций системы учебных планов и содержания обучения в лицеях и гимназиях, а также представлена основная цель схемы этапов обучения и спрогнозированы ожидаемые результаты.

Ключевые слова: непрерывность образования, трансформация содержания учебного процесса, инновации системы обучения, модернизация, профильное обучение, инновационные учебные технологии, индивидуализация обучения.

\section{References}

1 Pogashnik, I.M. (1995). Upravlenie razvitiem shkoly [School development management]. Moscow [in Russian].

2 Zinchenko, G.P. (1995). Affekt i intellekt v obrazovanii [Affect and intellect in education. Moscow [in Russian].

3 Marks, E. \& Petri, M. (1993). Razvitie shkoly: modeli i izmeneniia [School development: Models and changes]. Kaluha: Kaluzhskaia tipohrafiia standartov [in Russian].

4 Hutorski, A.V. (2003). Kliuchevye kompetentsii kak komponent lichnostno-orientirovannoi paradihmy obrazovaniia [Key competencies as a component of the personality-oriented paradigm of education]. Moscow [in Russian].

5 Kuryshev, A.S. (2007). Proektirovanie sistem nepreryvnoho otkrytoho professionalnoho obrazovaniia: teoria i praktika [Design of systems of continuous open professional education: theory and practice]. Kalininhrad: BFARF [in Russian].

6 Novikov, A.M. (2006). Metodika obucheniia. Vtoroe izdanie [Education methodology. Second edition]. Moscow Ehves [in Russian].

7 Kuznetsov, A., \& Pinski, A. (2002). Kontsepsiia profilnoho obrazovaniia na starshei stupeni obshcheobrazovatelnoi shkoly: proekt. Rukovoditeli proekta: A. Kuznetsov, A. Pinski [The concept of profile education at the senior level of secondary school: a project. Head of the project]. Moscow [in Russian].

8 Bolotov, V.A. (2003). Kompetentnostnaia model: ot idei k obrazovatelnoi prohramme [Competence model: from idea to educational program]. Moscow [in Russian].

9 Barbariga, A.A. (2005). Srednee i sredne-spetsialnoe obrazovanie v sovremennoi Anhlii [Secondary and secondary specialized education in modern England]. Kiev [in Russian].

10 Bessonov, R.V. (2006). Spetsifika prepodavaniia $v$ spetsializirovannoi shkole [Specificity of teaching in a specialized school]. Moscow: Pedahohika [in Russian].

11 Djýrınski, A.N. (2002). Razvitie obrazovaniia v sovremennom mire [Development of education in the modern world]. Moscow [in Russian].

12 Shmarion, Yu.V. (2003). Proektirovanie obrazovatelnykh sistem (sistemno-kontekstualnyi podkhod) [Design of educational systems (system-contextual approach)]. — Belgorod: Izdatelstvo Belhorodskoho hosudarstvennoho universiteta [in Russian].

13 Zagvázınski, V.I. (1990). Innovatsionnye protsessy v obrazovanii i pedahohıcheskoi nauke [Innovative processes in education and pedagogical science]. Tiumen [in Russian].

14 Degtárev, E.A. (2005). Voprosy upravleniia sovremennoi shkoloi [Management of the modern school]. Rostov na Donu [in Russian].

15 Alymova, N., \& Nadtochii, E. (2014). Shkolnoe samoupravlenie: struktura, rekomendatsii, normativy [School selfgovernment: structure, recommendations, standards]. Moscow: Uchitel [in Russian].

16 Sergeeva, V.P. (2011). Profilaktika obrazovaniia v obshcheobrazovatelnom uchrezhdenii [Prevention of education in a general educational institution]. Moscow [in Russian].

17 Gershýnski, B.S. (1990). Perspektivy razvitiia sistemy nepreryvnoho obrazovaniia [Prospects for the development of the continuous education system]. Moscow: Pedahohika [in Russian].

18 Pildee, M.B. (2011). Sistema obrazovatelnykh uchrezhdenii v kontekste modernizatsii obrazovaniia [The system of educational institutions in the context of modernization of education]. Volgograd [in Russian]. 
19 Bidenko, V.I. (1998). Standarty nepreryvnoho obrazovaniia: sovremennoe sostoianie [Standards in lifelong education: current state]. Moscow: Nauchno-issledovatelskii tsentr problem kachestva podhotovki [in Russian].

20 Lomakina, T.Yu. (2006). Sovremennyi printsip razvitia nepreryvnoho obrazovaniia [The modern principle of the development of lifelong educatio]. Moscow: Nauka [in Russian].

21 Serıkov, V.V. (1999). Obrazovanie i lichnost: teoriia i praktika proektirovaniia pedahohicheskikh sistem [Education and personality: theory and practice of design of pedagogical systems]. Moscow: Lohos [in Russian].

22 Ryndak, V.G. (1997). Nepreryvnoe obrazovanie i razvitie tvorcheskoho potentsiala uchitelia (teoriia vzaimodeistviia) [Continuous education and development of the teacher's creative potential (theory of interaction)]. Moscow: Pedahohicheskii vestnik [in Russian].

23 Chelysheva, T.V. (2001). Nepreryvnoe obrazovanie kak tselostnaia obrazovatelnaia sistema: teoreticheskie aspekty [Continuing education as an integral educational system: theoretical aspects]. Moscow: Apkipro [in Russian].

24 Alekseeva, L.N. (2004). Innovatsionnye tekhnolohii kak resurs eksperimenta [Innovative technologies as an experiment resource]. Moscow: Uchitel [in Russian].

25 Molchanova, T.K., \& Vinogradova, N.K. (2001). Sostavlenie obrazovatelnykh prohramm [Drawing up educational programs]. Moscow: Perspektiva [in Russian].

26 Dautova, O.B. \& Krylova, O.N.; Tryapitsina A.P. (Eds.). (2006). Sovremennye pedahohicheskie tekhnolohii v profilnom obuchenii [Modern pedagogical technologies in profile training]. Saint Petersburg: KAPO [in Russian].

27 Okolelov, O.P. (2013). Personalizirovannoe obuchenie: monohrafiia [Personalized learning: monograph]. Moscow: DirektMedia [in Russian].

28 Ovcharenko, E.N., \& Shogenov, A.A. (2008). Intehratsionnye protsesy kak faktor razvitia obrazovatelnoho prostranstva $v$ polikulturnom rehione: monohrafiia [Integration processes as a factor in the development of educational space in a multicultural region: monograph]. Moscow: FIRO [in Russian].

29 Romansev, G.M., Fedorov, V.A., Osipova, I.V., \& Tarasyuk, O.V. (2005). Professionalnye pedahohicheskie poniatiia: slovar [Professional pedagogical concepts: dictionary]. Ekaterinburg: Izdatelstvo Rossiskoho hossudarstvennoho professionalnopedahohicheskoho universiteta [in Russian].

30 Dymarskaia, O.Ia., Konstantınovsk1, D.L., Voznesenska1a, E.D., \& Cherednichenko, G.A. (2006). Sotsialno-humanitarnoe obrazovanie: orientatsii, praktiki, resursy sovershenstvovaniia [Social and humanitarian education: orientations, practices, resources for improvement]. Moscow: TSSP [in Russian].

31 Bitúkov, V.K., Chertov, E.D., \& Kondaýrov, A.T.: nauchnyi redaktor Z.D. Zhukovskaya (2003). Proektirovanie i realizatsiia mnohourovnei modeli professionalnoho obrazovaniia [Design and implementation of a multilevel vocational education model]. — Voronezh: B.I. [in Russian].

32 Asmolov, A.G., Býrmenska1a, G.V., \& Volodarska1a, I.A. (2011). Formirovanie universalnykh uchebnykh deistvii $v$ osnovnoi shkole: ot deistviia mysli [Formation of universal educational actions in basic school: from the action of thought]. Moscow [in Russian].

33 Iambýrg, E.A. (2004). Harmoniia pedahohicheskikh paradihm - stratehiia razvitiia obrazovaniia. Sbornik nauchnykh statei po materialam Mezhdunarodnoi nauchno-prakticheskoi konferentsii «Problemy vnedrenia psiholoho-pedahohicheskikh issledovanii $v$ sistemu obrazovaniia» [Harmony of pedagogical paradigms - a strategy for the development of education. Collection of scientific articles based on the materials of the international scientific-practical conference "Problems of the introduction of psychological and pedagogical research into the education system»]. Moscow [in Russian]. 